\title{
Family Change and Implications for Family Solidarity and Social Cohesion
}

\author{
Roderic Beaujot \\ Zenaida Ravanera \\ Population Studies Centre \\ Department of Sociology \\ University of Western Ontario \\ London, Ont N6A 5C2 \\ Rbeaujot@uwo.ca \\ Ravanera@uwo.ca
}

\begin{abstract}
Social cohesion can be viewed in terms of common projects and networks of social relations that characterize families, communities and society. In the past decades, the basis for family cohesion has shifted from organic to mechanical or from breadwinner to collaborative model. As in many Western countries, data on family change in Canada point to a greater flexibility in the entry and exit from relationships, a delay in the timing of family events, and a diversity of family forms. After looking at changes in families and in the family setting of individuals, the paper considers both intra-family cohesion and families as basis for social cohesion. Implications are raised for adults, children and public policy.
\end{abstract}

Key Words: Family change, solidarity, cohesion, lone parenthood, divorce, cohabitation, family policy 
Roderic Beaujot and Zenaida Ravanera

\section{Résumé}

La cohésion sociale peut se voir à travers les projets communs et les réseaux des relations sociales qui caractérisent les familles, les communautés et les sociétés. La base de cohésion familiale est passée d'organique à mécanique, pour utiliser les termes de Durkheim, ou vers un modèle de collaboration plutôt qu'une partage asymétrique de tâches. Comme dans d'autres sociétés orientales, la famille au Canada est devenue plus flexible par rapport aux entrées et sorties d'unions, il y a un délais dans les événements familiaux, et une variété de formes de familles. Après un regard sur les changements dans les familles et dans la situation familiale des individus, nous considérons la cohésion intrafamiliale et la famille comme base de cohésion sociale. Nous discutons des impacts sur les adultes, les enfants et la politique publique.

Mots-clés: Changements dans la famille, cohésion, parents-seuls, divorce, cohabitation, politique familiale

\section{Introduction}

The context of significant socio-economic change, including that resulting from globalization and the 24/7 economy, brings attention to social cohesion, one of the oldest concepts of the social sciences. How will the society hold together, and what will be the relation of individual to society? Similar issues are raised when there is profound family change: what is holding families together and what are the links between individuals and families?

The concern here is with the family dimensions of social cohesion, including ways in which families may be involved in cohesion at the group, community or societal level. The paper starts with definitions of social cohesion and social capital and reviews the theoretical links between changes in the families and social cohesion. Various family changes in Canada are then presented and how these changes have affected social cohesion both within families and at the societal level. 
Family Change and Implications for Family Solidarity and Social Cohesion

\section{Social Cohesion: Common Projects and Social Networks}

Social cohesion refers to the relation between individuals and groups, in terms of inclusion, participation and belonging. Rosell (1995) defines social cohesion as "involving building shared values and communities of interpretation, reducing disparities in wealth and income, and generally enabling people to have a sense that they are engaged in a common enterprise, facing shared challenges and that they are members of the same community." Others have broken down the concept into economic dimensions of inclusion and equality, political dimensions of legitimacy and participation, and sociocultural dimensions of recognition and belonging (Bernard, 1999; Jenson, 1998).

One way of viewing social cohesion is through common projects and associated alliances that bring individuals together (Cunningham, 2000). At the macro level, this "project de société" or common purpose can be defined in terms of collective security and solidarity, but it can also be defined in terms of social programs. At the family level, there are various ways in which common projects can be defined, with the potential for belonging, inclusion and participation. There is of course the "marital" relation between two people, which may be defined as a "projet de couple" wherein people create and re-create their own relationships (Roussel, 1987). This "couple project" typically involves links across gender. Children may be another common project between given individuals, including links across generations. If one defines families as individuals coming together to earn a living and care for each other, then the common project can be defined in terms of sharing in earning and caring (Beaujot, 2000).

Another way of looking at social cohesion is from the point of view of how individuals are integrated into groups. These relations between individuals and groups generate social capital that includes social relations or networks (Bourdieu, 1985; Astone et al, 1999; Coleman, 1990). As a sociologist, Coleman's concept of social capital assumes that "individuals are embedded in a system of normative obligations created by social consensus" (Furstenberg, 2005: 810). Members benefit from the associated symbolic and material resources. From a political science perspective, Putman $(1995,2000)$ sees social capital in terms of social trust and civic participation. Either approach uses the concept of networks. Thus, Portes (1998: 8) defines social capital as the "ability to secure benefits through membership in networks and other social structures". Similarly, Stone et al. (2003) refer to "networks of social relations characterized by norms of trust and reciprocity." These networks of social relations can characterize various groups including families, communities and societies. 


\section{Family Cohesion: Organic Solidarity to Solidarity Based on Collaborative Model}

Durkheim had considered social cohesion in terms of organic and mechanical solidarity. Organic solidarity is based on a division of labour, while mechanical solidarity is based on an immediate identification with others. He sees organic solidarity, through specialization and interdependence on instrumental questions, as the basis for families. In particular, he considered that the sexual division of labour holds families together:

Permit the sexual division of labour to recede below a certain level and conjugal society would eventually subsist in sexual relations preeminently ephemeral (Durkheim 1960 (1893): 60).

Thus Durkheim saw this "modern" form of solidarity as applying to families from time immemorial. Families were units of economic activity involving typically some specialization of tasks by gender. While we know little about the inner dynamics of families in pre-modern times, some historians have believed they were based on organic solidarity (Shorter 1975; Stone 1977; Ariès 1962); that is, families were not so much homes as places of work. Workplaces benefit from clear authority patterns and allocations of tasks.

Mechanical solidarity is an immediate (expressive) identification with others who shared a common sense of values and belonging ("these are my people"). As societies have changed from mechanical to organic solidarity, the family ideal has involved a change in the opposite direction. Since families are no longer units of economic production, they need not be based on a division of labour, they can be held together by a sense of common identity. This has also been referred to as the de-institutionalization of the family, from institution to companionship (Burgess et al., 1963), from orderly replacement of generations to permanent availability (Farber 1964), and from instrumental to expressive relationships (Scanzoni and Scanzoni 1976; Thadani 1978). The focus has changed from a division of labour to the quality of the dyadic relation between partners (Lesthaeghe, 1995). When the family was basically a unit of production and survival, relationships were instrumental; as families became a "private sphere," nurture and affection became the basis for relationships (Hareven 1977). Obviously, sentiment is a weaker basis for stable relationships and the need for continuous gratification puts heavy demands on relationships, which may not always fulfill the high expectations. People are more prone to abandon family ties when their emotional well being is not satisfied. 
Family Change and Implications for Family Solidarity and Social Cohesion

While this shift may have led to weaker basis for family solidarity, Oppenheimer (1997) observes that the companionship model that is no longer based on the organic solidarity of a gender division of labour is associated with lower risk - it provides insurance against the inability or unwillingness of the breadwinner to provide for (especially former) spouse and children. This model, also known as a collaborative model, suggests that there is solidarity in terms of both instrumental and expressive questions, in earning a living and caring for each other. In effect, the classifications proposed by Durkheim need not be seen as mutually exclusive. There could be a two-fold classification in terms of the presence or absence of mechanical and organic solidarity. A relationship based only on mechanical solidarity may be called a "pure relationship," while one based on organic solidarity may be an "instrumental relationship," and if both are present it becomes a collaborative model. This recognizes the importance of both instrumental and expressive activities for families. Of course, if neither is present there is no relationship.

\section{Family Change: A Second Demographic Transition}

The shift in the basis of family solidarity has implications for integration of individuals into society as well. The collaborative model of family solidarity includes not only the expressive exchanges with a love-mate, but also working together to establish a good life. These relationships are mostly defined as a twoworker model, where both earning and caring are shared in order to establish secure middle class status (Coltrane, 1995). Following Oppenheimer's (1988) theory of marriage timing, this two-worker model brings delays in family formation as young people seek better integration in the labour market by first finishing their education and establishing their work lives. In terms of having children, women who are in complementary-roles relationships have children early, possibly as a means of social cohesion, while in the collaborative model women first establish themselves at work then have children (Ranson, 1998, Beaujot and Muhammad, 2006).

The modification of the foundation for family solidarity is just one of the many changes that have transformed families. In demography, family change is largely theorized in terms of two demographic transitions: a long-term change (from about 1870 to 1950), which brought smaller families; and another change (from about 1960 to the present), which especially involved increased flexibility in marital relationships (Lesthaeghe, 1995; Beaujot, 2000: 85-96).

The first transition involved a change in the economic costs and benefits of children, along with a cultural environment that made it more appropriate to control family size. The second demographic transition has been linked to 
secularization and the growing importance of individual autonomy. This includes a weakening of the norms against divorce, pre-marital sex, cohabitation and voluntary childlessness. Value change has promoted individual rights along with less regulation of the private lives of individuals by the larger community. There is a heightened sense that both women and men should make their own choices in terms of relationships and childbearing. Diversity is valued, in living arrangements and in family forms. For instance, the pressure to accept same-sex marriages came not only from those who sought the right to live in these relationships with equal status to heterosexuals, but also from the broader population who see diversity and plurality as themselves valuable.

This conceptualization confirms the uniqueness of the 1950s as a period between the two transitions. Not only was this the peak of the baby boom, but it was also a period of marriage rush, as marriage occurred at young ages and high proportions of persons married at least once in their lives. It was possibly a "golden age of the family," where many families corresponded to the ideal of domesticity, especially in the suburbs, with family cohesion based on an asymmetric or specialized division of labour, and consequently there was less variability (Skolnick, 1987: 6-16). Women were the links to networks in the neighbourhoods, engaging in voluntary work and associations.

Subsequent research has made it clear that not all was ideal in this golden age. Isolated housewives in particular experienced the "problem with no name" (Freidan, 1963: 15). Since the task of maintaining the home and linking to the community had been assigned to women, men became less competent at the social skills needed to nourish and maintain relationships (Goldscheider and Waite, 1991: 19). The idealism of the time also introduced blinders regarding some realities of family life, including violence and abuse. Given a general denial that such things could ever occur in families, there was little recourse for the victims of violence. There was also a lack of autonomy, especially for women, to pursue routes other than the accepted path (Veevers, 1980). Childless couples were considered selfish, single persons were seen as deviants, working mothers were considered to be harming their children, single women who became pregnant were required either to marry or to give up the child in order to preserve the integrity of the family. In hindsight, we can observe that there were pent-up problems that were preparing the way for the second transition that started in the 1960s.

\section{Family Transformation in Canada}

As in many Western countries, families in Canada have been transformed over the decades since the 1960s. In this section, these changes are discussed using 
Family Change and Implications for Family Solidarity and Social Cohesion

indicators such as various rates of family formation and dissolution (Table 1), family living arrangements of individuals (Table 2) and, the prevalence of various household units (Table 3). It is not easy to identify the direct impact of the changes on both family solidarity and social cohesion and this research simply attempts to show the implications of these changes to individuals, families and society. In subsequent sections, however, an attempt is made to explore the relation between family changes on one hand and family solidarity and social cohesion on the other citing studies that make use of Canadian survey data.

\section{Looseness of Marital Bonds through Cohabitation and Divorce}

Data on family change document a greater looseness of the marital bond as seen mainly through divorce and cohabitation. The law permitting divorces on grounds other than adultery dates only from 1968. Per 100,000 married couples, there were under 200 divorces in each year over the period 1951-1966 compared to 1000 in 1976 and 1080 in 2003 (Table 1). Cohabiting unions were not specifically enumerated in the 1976 census, although some 0.7 percent of couples indicated that they were living common-law. By 1986, most Statistics Canada data no longer distinguished between married and cohabiting couples. The 2001 census determined that 16.4 percent of couples were cohabiting (Table 1). The 1995 General Social Survey found that among persons born between 1951 and 1970, two out of five have lived in a cohabiting union, and over half of first unions taking place since 1985 have been cohabitations rather than marriages (Dumas and Bélanger, 1997: 135, 139).

The high rates of divorce are in themselves an indicator of the weaker bond that holds families together and family dissolution itself is related to the manner of its formation. The increased numbers of families formed by cohabitation has increased the number of marital separations. Le Bourdais et al. (2000) analyse this question separately for Quebec and the rest of Canada, based on the 1995 General Social Survey. Outside of Quebec, looking only at couples with children who were in their first union, the marriages that were preceded by cohabitation had $66 \%$ higher chance of separation, and those that remained common law without marriage had five times the chance of separation, compared to the direct marriages. In Quebec, direct marriages were less stable than in the rest of Canada, but they did not differ from the marriages preceded by cohabitation. However, those that remained as cohabiting unions had 2.4 times the likelihood of separation compared to direct marriages. With the widespread practice of cohabitation before marriage, marriages preceded by cohabitation are becoming less selective, and cohabitation itself is becoming more of an alternative to marriage, but the variability in the types of cohabitation 
Roderic Beaujot and Zenaida Ravanera

makes for more instability in these unions (Le Bourdais and Lapierre-Adamcyk, 2004). Clearly, cohabitation postpones marriages and it is related to lower marital stability (Wu, 1999).

\section{Rise in Lone Parent Families}

Both divorce and cohabitation have contributed to a rise in lone parent families. Considering only families with children, the proportion who are lone-parents increased from $11 \%$ in the 1961 to $25 \%$ in 2001 (Table 1). Considering all individuals, the proportion of women aged 15 and older who are lone parents in 1981 was $6.3 \%$, which increased to $8.7 \%$ in 2001 (Table 2).

The pathway towards lone parenthood has dramatically changed in the last half of the century. The parents in two-thirds of lone parent families in 1951 were widowed compared to one-fifth in 2001 (Table 3). In contrast, $3 \%$ of parents (in lone parent families) in 1951 were divorced, which increased ten fold (to $31 \%$ ) in 2001. The lone-parent families where the parent is never married, which includes persons who had previously cohabited, has also increased and represents $27 \%$ of the total in 2001. Births to non-married women increased from $4 \%$ of all births in 1951 to $38 \%$ in 2001 (Table 1). The proportion of loneparent families that are male-led is relatively constant, representing 18.7 percent of lone parent families in 2001 (Table 3).

The marital histories of parents show up in the complexity in the lives of children. For instance, among children under 12 in the 1994-95 National Longitudinal Survey of Children and Youth, $78.7 \%$ were with two biological parents, $4.3 \%$ were with a biological parent and a step-parent, $15.5 \%$ were with a lone parent, $1.4 \%$ were in another parenting situation, and $0.1 \%$ had no custodial parent (Beaujot, 2000: 271).

The increasing fragility of marriages and other forms of partnerships, and the associated increase in the proportion of lone-parent families and step- and blended families, has been detrimental for children. Some studies remind us of the resilience of children in the face of family breakdown (see, e.g., Haddad, 1998); however, the consensus in the literature is that the growing instability in unions has had adverse effects on children. For instance, Kerr (2006) finds that children in lone-parent families and step-families have higher levels of income poverty and also greater behavioural and psychological problems. Mac Con (2006) finds that children from families that are non-intact and less cohesive families, as well as from families with low socioeconomic status, are more likely to experience high levels of emotional disorder. Marshall (2007) finds that teenagers are significantly more likely to do homework if they live in intact two- 
Table 1

Summary Statistics on Family Change, Canada: 1941-2004

\begin{tabular}{|c|c|c|c|c|c|c|c|c|c|c|c|}
\hline Variable & 1941 & 1951 & 1961 & 1971 & 1976 & 1981 & 1986 & 1991 & 1996 & 2001 & 2004 \\
\hline \multicolumn{12}{|l|}{ Divorces per 100,000 } \\
\hline married couples & -- & 180 & 180 & 600 & 990 & 1129 & 1220 & 1110 & 1130 & 1100 & $1080 *$ \\
\hline $\begin{array}{l}\text { Common-law couples as a } \\
\text { percent of all couples }\end{array}$ & -- & -- & -- & -- & 0.7 & 6.4 & 8.2 & 11.2 & 13.7 & 16.4 & -- \\
\hline $\begin{array}{l}\text { Lone-parent families as a } \\
\text { percent of all families } \\
\text { with children }\end{array}$ & 9.8 & 9.8 & 11.4 & 13.2 & 14.0 & 16.6 & 18.8 & 20.0 & 22.3 & 24.7 & -- \\
\hline \multicolumn{12}{|l|}{ Births to non-married women } \\
\hline as a percent of all births & 4.0 & 3.8 & 4.5 & 9.0 & -- & 16.7 & 18.8 & 28.6 & 36.9 & 38.2 & 35.9 \\
\hline \multicolumn{12}{|l|}{ Median age at first marriage } \\
\hline Brides & 23.0 & 22.0 & 21.1 & 21.3 & 21.6 & 22.5 & 23.9 & 25.1 & 26.3 & 26.0 & $27.0^{*}$ \\
\hline Grooms & 26.3 & 24.8 & 24.0 & 23.5 & 23.7 & 24.6 & 25.8 & 27.0 & 28.3 & 27.0 & $29.0^{*}$ \\
\hline \multicolumn{12}{|l|}{ Births to women aged $30+$} \\
\hline as a percent of all births & 35.6 & 36.2 & 34.1 & 21.6 & 19.6 & 23.6 & 29.2 & 36.0 & 43.7 & 46.9 & 48.5 \\
\hline Median age at first birth & 24.3 & 23.5 & 22.8 & 22.9 & 23.6 & 24.5 & 25.1 & 26.2 & 27.1 & 27.6 & 28.0 \\
\hline $\begin{array}{l}\text { Total fertility rate } \\
\text { (average births per women) }\end{array}$ & 2.8 & 3.5 & 3.8 & 2.1 & 1.8 & 1.7 & 1.6 & 1.7 & 1.6 & 1.5 & 1.5 \\
\hline
\end{tabular}

Notes: For 1941-71 births to non-married women are designated as illegitimate births.

Median age at first birth: mean age shown for 1986-96

*refers to 2003 data

Sources: Statistics Canada, no. 82-553, 1992: Tables 10, 16, 3; Statistics Canada, no. 82-552, 1992: Table 14;

Statistics Canada, no. 84-212, 1995; Statistics Canada, no. 91-209, 1996: 19; Statistics Canada, no. 84-204, 1971;

Statistics Canada, no.84-213,1991,1987-1988, 2003;

Special tabulations, Statistics Canada; CANSIM, Statistics Canada; Beaujot and Kerr, 2004:21; 1941 Census, vol. V.: Table 19;

1951 Census, vol. III.: Table 136; Statistics Canada, 84-210, 1996, 2001, 2004; Statistics Canada, 84-214, 1996 
Roderic Beaujot and Zenaida Ravanera

Table 2

Marital Status, Parental Status, and Living Arrangements by Gender and Age Group for Canada: 1981 and 2001

\begin{tabular}{|c|c|c|c|c|c|c|c|c|}
\hline \multirow{2}{*}{1981} & \multicolumn{4}{|c|}{ Men } & \multicolumn{4}{|c|}{ Women } \\
\hline & 15-29 & $30-64$ & $65+$ & Total & $15-29$ & $30-64$ & $65+$ & Total \\
\hline \multicolumn{9}{|l|}{ Marital Status } \\
\hline Married & 29.9 & 82.7 & 73.1 & 62.0 & 41.6 & 78.2 & 38.3 & 59.7 \\
\hline Never married & 68.3 & 9.6 & 8.3 & 31.3 & 55.1 & 7.4 & 9.5 & 24.5 \\
\hline Widowed & 0.0 & 1.2 & 14.3 & 2.2 & 3.2 & 8.4 & 2.9 & 5.8 \\
\hline Divorced/Separated & 1.8 & 6.5 & 4.2 & 4.5 & 0.1 & 6.0 & 49.3 & 10.0 \\
\hline Total & 100.0 & 100.0 & 100.0 & 100.0 & 100.0 & 100.0 & 100.0 & 100.0 \\
\hline \multicolumn{9}{|l|}{ Living Arrangement } \\
\hline Living with spouse & 29.9 & 82.8 & 75.1 & 62.3 & 41.4 & 77.9 & 40.6 & 60.0 \\
\hline Lone parent & 0.2 & 2.1 & 1.9 & 1.4 & 3.2 & 8.6 & 5.6 & 6.3 \\
\hline Living with parents & 52.4 & 2.6 & 0.1 & 20.9 & 41.1 & 1.5 & 0.1 & 15.5 \\
\hline Non-family living & 17.5 & 12.5 & 22.8 & 15.4 & 14.3 & 12.0 & 53.6 & 18.2 \\
\hline Total & 100.0 & 100.0 & 100.0 & 100.0 & 100.0 & 100.0 & 100.0 & 100.0 \\
\hline \multicolumn{9}{|l|}{ Parental Status } \\
\hline Living with chilldren & -- & -- & -- & -- & 26.6 & 65.0 & 8.5 & 43.5 \\
\hline Not Living with children & -- & -- & -- & -- & 73.4 & 35.0 & 91.5 & 56.5 \\
\hline Total & -- & -- & -- & -- & 100.0 & 100.0 & 100.0 & 100.0 \\
\hline \multirow{2}{*}{2001} & \multicolumn{4}{|c|}{ Men } & \multicolumn{4}{|c|}{ Women } \\
\hline & 15-29 & $30-64$ & $65+$ & Total & 15-29 & $30-64$ & $65+$ & Total \\
\hline \multicolumn{9}{|l|}{ Marital Status } \\
\hline Married & 9.4 & 63.9 & 74.1 & 51.4 & 15.7 & 63.2 & 43.9 & 48.7 \\
\hline Common law & 9.6 & 11.7 & 2.7 & 9.9 & 13.0 & 10.2 & 1.2 & 9.4 \\
\hline Never married & 80.2 & 14.7 & 5.3 & 30.1 & 69.6 & 10.9 & 5.5 & 24 \\
\hline Divorced/separated & 0.8 & 9.0 & 6.8 & 6.6 & 1.5 & 12.6 & 7.2 & 9.1 \\
\hline Widowed & 0.0 & 0.7 & 11.1 & 2.0 & 0.1 & 3.0 & 42.2 & 8.8 \\
\hline Total & 100.0 & 100.0 & 100.0 & 100.0 & 100.0 & 100.0 & 100.0 & 100.0 \\
\hline \multicolumn{9}{|l|}{ Living Arrangement } \\
\hline Living with Spouse & 8.9 & 63.5 & 73.5 & 51.0 & 15.2 & 62.8 & 43.2 & 48.3 \\
\hline Living with CL partner & 9.7 & 11.8 & 2.7 & 10.0 & 13.1 & 10.2 & 1.2 & 9.4 \\
\hline Lone parent & 0.6 & 2.8 & 2.1 & 2.1 & 5.2 & 10.4 & 7.8 & 8.7 \\
\hline Living with parents & 63.3 & 4.6 & 0.2 & 19.0 & 52.2 & 2.4 & 0.1 & 13.9 \\
\hline Non-family living & 17.4 & 17.3 & 21.4 & 17.9 & 14.2 & 14.2 & 47.6 & 19.7 \\
\hline Total & 100.0 & 100.0 & 100.0 & 100.0 & 100.0 & 100.0 & 100.0 & 100.0 \\
\hline $\begin{array}{l}\text { Parental Status } \\
\text { Living with children } \\
\text { under } 25\end{array}$ & 8.6 & 50.2 & 2.6 & 33.1 & 19.1 & 53.5 & 0.8 & 36.6 \\
\hline $\begin{array}{l}\text { Not living with children } \\
\text { under } 25\end{array}$ & 91.4 & 49.8 & 97.4 & 66.9 & 80.9 & 46.5 & 99.2 & 63.4 \\
\hline Total & 100.0 & 100.0 & 100.0 & 100.0 & 100.0 & 100.0 & 100.0 & 100.0 \\
\hline
\end{tabular}

Note: In 1981, common law is not measured separately; In 1981, men's parenthood status is not available.

Source: Computed from 2001 Census PUMF; 1981 Census, PUMF on Individuals. 
Family Change and Implications for Family Solidarity and Social Cohesion

parent families. In the longer term, Provencher et al., (2006) find that children's family experiences in their early years influence their own behaviour in matters of family formation and dissolution; children raised in non-intact families have higher chances of forming a conjugal union at a young age, more likely to cohabit rather than marry, have a child outside of a union and experience separation.

\section{Delay in Timing of Family Events and Low Fertility}

But some family changes have benefited children, especially having more mature parents with more human capital and two incomes. The median age at first marriage declined over this century to reach a low of just over 21 years for brides and 23 years for grooms in the early 1970s, but this gradually increased so that by 2004, the median ages are 27 and 29 for women and men respectively (Table 1). More generally, over the birth cohorts 1916-20 to 1941-45 there was a general downward trend in the age at home leaving, first marriage, first birth, last birth and home leaving of the children. Among these cohorts, the tendency was not only to marry early, but over a relatively narrow range of ages (Ravanera and Rajulton, 1996; Ravanera et al., 1998a and 1998b). Conversely, the subsequent cohorts have experienced an upward trend in age (and an increase in the age range) at experience of family events.

This trend of postponement is seen in the proportion of youth living at home, which has been increasing at older ages. In 2001, this represented 43 percent of men and 35 percent of women aged 25 , and 20 percent of men and 12 percent of women aged 29 (Beaujot and Kerr, 2007: 8). Other indicators of the delays are the increasing proportion of births to women aged 30 and over - from $34 \%$ in 1961 to $49 \%$ in 2004, the increasing median age of women at first birth - from 23 years old in 1961 to 28 in 2004 (Table 1), and the decreasing proportion of married men and women aged 15-29-42\% of women in 1981 were married but only $16 \%$ in 2001 (Table 2 ).

Later home leaving can be used as an indicator of family cohesion. While part of the reason for these delays is the difficult economic situations that youth face as they pursue more education, there is probably a lower generation gap, with more agreement between parents and youth, allowing young people to feel comfortable at home. It can be argued that the delays in young adult transitions, as does a longer life span, have permitted more intra-family transfers. These delays may be interpreted as a longer period of adolescence, that Côté and Allahar (1994) have called a Generation on Hold. But the delays also reflect the needs of both men and women to put off the entry into relationships, and especially childbearing, until they are better able to handle the trade-offs 
Table 3

Households and Families by Type for Canada: 1951 - 2001

\begin{tabular}{|c|c|c|c|c|c|c|}
\hline Variable & 1951 & 1961 & 1971 & 1981 & 1991 & 2001 \\
\hline $\begin{array}{l}\text { Marital status by lone parent } \\
\text { families }\end{array}$ & 100.0 & 100.0 & 100.0 & 100.0 & 100.0 & 100.0 \\
\hline Never married & 1.5 & 2.7 & 7.7 & 9.8 & 17.5 & 27.4 \\
\hline Married, spouse absent & 28.9 & 31.3 & 33.7 & 31.3 & 26.9 & 22.2 \\
\hline Widowed & 66.5 & 61.5 & 46.5 & 32.7 & 22.9 & 19.8 \\
\hline Divorced & 3.1 & 4.5 & 12.1 & 26.3 & 32.7 & 30.5 \\
\hline Lone Parent (\% of Families) & 9.9 & 8.4 & 9.4 & 11.3 & 13.0 & 15.7 \\
\hline Lone parent familes & 100.0 & 100.0 & 100.0 & 100.0 & 100.0 & 100.0 \\
\hline Male-led & 22.6 & 21.6 & 21.2 & 17.4 & 17.6 & 18.7 \\
\hline Female-led & 77.4 & 78.4 & 78.8 & 82.6 & 82.4 & 81.3 \\
\hline Husband-wife families & 100.0 & 100.0 & 100.0 & 100.0 & 100.0 & 100.0 \\
\hline with children at home & 67.9 & 70.9 & 68.3 & 64.2 & 59.7 & 51.7 \\
\hline without children at home & 32.1 & 29.1 & 31.7 & 35.8 & 40.3 & 48.3 \\
\hline Total private households & 100.0 & 100.0 & 100.0 & 100.0 & 100.0 & 100.0 \\
\hline Family households & 88.7 & 86.7 & 81.6 & 75.2 & 72.2 & 70.5 \\
\hline One-family households & 82.0 & 83.0 & 79.6 & 74.1 & 71.1 & 68.8 \\
\hline Multiple-family households & 6.7 & 3.7 & 2.0 & 1.1 & 1.2 & 1.8 \\
\hline Non-family households & 11.3 & 13.3 & 18.3 & 24.8 & 27.8 & 29.5 \\
\hline of one person & 7.4 & 9.3 & 13.4 & 20.3 & 22.9 & 25.7 \\
\hline of two or more person & 3.9 & 4.0 & 4.9 & 4.5 & 4.9 & 3.7 \\
\hline
\end{tabular}

Source: Péron et al., 1999: 27,74,75; Beaujot and Kerr, 2004:230; Statisticss Canada, 93-312; Statisticss Canada, 95F0487XCB2001 001 
between investing in themselves and investing in reproduction. While parents complain of the KIPPERS phenomenon (Kids In Parents' Pockets Eroding Retirement Savings), transfers to children are probably stronger when they are living in the same household as the parents, thus subsidizing their entry into the labour market. These transfers from parents also encourage a two-worker model, reducing the early union formation of women, and the dependence of women on men.

However, the benefits of delays in transitions have not been experienced equally. Children stay at school longer if their mothers are employed (Ravanera et al., 2003). Stated differently, delay in family formation is more likely to occur for persons with greater parental resources that provide more opportunities to pursue higher education and to establish careers (Ravanera et al., 1998b, 2002), which in turn have consequences for family life. Women with more human capital are more likely to get married and stay married (McLanahan, 2004, McQuillan, 2006).

Later home leaving facilitates labour market integration; however, home leaving is earlier in the case of children from lone parent and step families (Zhao et al., 1995). Research from the United States indicates that leaving home at a very young age, particularly when this does not involve attending school, has a variety of negative consequences for establishing successful career patterns and stable families (Goldscheider and Goldscheider, 1999: 209-210). Early home leaving is linked to lower educational aspirations, lower educational attainment, and this would be particularly the case when the departure is due to a push factor, such as family conflict.

Similarly, later reproduction allows for a longer period of investment in oneself before investing in reproduction. However, even in two-parent families, there are increasing income differentials to the disadvantage of younger first-time mothers (Lochhead, 2000). For women who have children aged 0-5, there are increased differentials between younger mothers aged 20-24 and mothers aged 25-29 in terms of proportions working full-time (Beaujot and Kerr, 2007). Drolet (2002) finds that the wages of women who had their children later did not differ from those who had no children, but women who had their children earlier than the average for their level of education had lower average wages.

Among women with children under age five, there is also a greater likelihood of being lone-parents among the younger compared to the older women (Beaujot and Kerr, 2007). While the income situation of lone parents is improving, these improvements apply to lone parents who are older and with more human capital (Myles, et al., 2006). The disadvantaged situation of young lone parents remains significant. 
Roderic Beaujot and Zenaida Ravanera

Stated differently, there is a relationship between demographic and socioeconomic vulnerability. Kiernan (2002) speaks of a "long arm of demography" in the sense that family demographics are differentiated based on the extent to which individuals are disadvantaged, and this selectivity has further implications for subsequent vulnerability. Kiernan pays particular attention to youthful parenthood, unmarried families, and parental separation and divorce, as demographics that are linked to disadvantage.

The postponement of child-bearing has contributed to Canada's below replacement levels of fertility. The total fertility rate reached a peak of 3.9 in 1957, declined to 2.2 in 1971, and has declined more slowly from 1.7 to 1.5 births per woman over the period 1980 to 2004 (Table 1). Among husband-wife families, the proportion without children at home increased from $35.8 \%$ in 1981 to $48.3 \%$ in 2001 (Table 3). Among all households, the proportion with children declined from 52.5\% in 1981 to 42.9\% in 2001 (Beaujot and Kerr, 2004: 230).

In addition to the implication of low fertility to society in terms of its impact on age-structure and labour force supply, children have direct influence on family solidarity and in generation of social capital (discussed in a separate section below).

\section{Diversity Across Families and Increase in One Person Households}

An outcome of changes in family formation and dissolution and in shift in values about families is diversity of families. The 2001 census was the first to record same-sex couples, which represented 0.5 percent of couples (Statistics Canada, 2002a: 24). Considering only families with children, the proportion who are lone-parent increased from $12 \%$ in the 1960s to $26 \%$ in 2001 (Beaujot and Kerr, 2004: 230). Another 10\% are step-families so that slightly more than one-third of families with children do not conform to the "traditional" family image of a mother, father and their biological (or adopted) children (Statistics Canada, 2002b: 9). Among step-families with children under 25, 36.7\% are blended step-families with at least one common child, another $43.0 \%$ have a mother plus a stepfather, $11.0 \%$ have a father and stepmother, and $9.3 \%$ have children from both sides but no common children (Juby and Le Bourdais, 2005: 21).

As discussed above, some form of families could be disadvantaged. However, diversity is seen as valuable, with the norm that alternative family arrangements are to be supported rather than forcing everyone to conform to a common 
Family Change and Implications for Family Solidarity and Social Cohesion

standard like the "heterosexual nuclear family." In effect, there is greater tolerance for diversity, a factor that is positive for social cohesion.

Over the period 1951-2001, there has also been an increase in the relative numbers of non-family households, and especially of one-person households, along with a decline especially in multi-family households (Table 3). Essentially all family households consist of one nuclear family, and the majority of nonfamily households comprising one person. Living in non-family households occurs especially for the elderly who have previously lived in families, and for the young who are between families.

One advantage of living alone is the independence that it brings. However, an important reason people give for preferring marriage or cohabitation over living alone is that there is a built-in companionship. For adults, marriage brings various benefits, especially economic benefits to women and health and longevity benefits to men (Waite, 1995). For instance, Feng et al. (2007) find significant problems of persistent low income among working-aged unattached individuals, who represent $11 \%$ of the population but over a third of persons with low income. At ages 45-54, one-quarter of persons who were unattached over a six year period also had low income over this period.

\section{Measures of Family Solidarity}

In spite of changes in the family Rajulton and Ravanera (2006), using the General Social Survey on Social and Community Support, find that the family support system - in terms of giving and receiving - is still in good shape, and family concerns remain of utmost importance in people's lives. In particular, $90 \%$ of Canadians contribute to family solidarity in at least one of three ways (affinity, contact, functional exchange). Of the total population, 25\% gave or received emotional support from family members, $48 \%$ who made contact at least once per week (opportunity structure), and $84 \%$ who had at least one functional exchange (services of any kind) with family members (Table 4). Putting these three together shows that $23 \%$ of the population is involved in all three forms of support (defined as "tight-knit") while $10 \%$ are associated with none of these (defined as "detached"). The other common categories are "purely functional" (39\% have a functional exchange but no giving or receiving of emotional support and less frequent contact than once per week) and "obligatory" (21\% have no emotional support but both functional exchange and contact at least once per week).

Exchanges are most predominant for couples with or without children and lone parents, and they are lowest for persons living alone. The analysis of 
determinants shows the importance for family solidarity of the presence of children rather than questions of education and income.

Table 4

Family Social Support and Types of Family Social Support (\%) by Gender for Canada: 1996

\begin{tabular}{lccc}
\hline \multicolumn{1}{c}{ Variable } & Total & Men & Women \\
& & & \\
\hline Family Social Support & & & \\
& & & \\
Affinity & 25.1 & 24.0 & 26.0 \\
Opportunity Structure & 48.5 & 44.0 & 52.0 \\
Functional & 83.4 & 84.0 & 83.0 \\
N & & & \\
& 12756 & 5527 & 7229 \\
& & & \\
Types of Family Social Support & & & \\
& & & \\
Detached & 10.0 & 10.0 & 9.0 \\
Purely Functional & 39.0 & 44.0 & 34.0 \\
Purely Proximity & 2.0 & 2.0 & 2.0 \\
Pure Affinity & 0.5 & 0.4 & 0.5 \\
Obligatory & 21.0 & 18.0 & 24.0 \\
Empathic & 3.0 & 3.0 & 4.0 \\
Sociable & 1.5 & 1.3 & 1.7 \\
Tight-Knit & 23.0 & 21.0 & 25.0 \\
& & & \\
N & 12756 & 6279 & 6477 \\
& & & \\
\hline Sorce: Rajltn & &
\end{tabular}

Source: Rajulton and Ravanera, 2006:248; Statistics Canada, GSS, 1996.

The amount of time spent with family is another measure of family solidarity. When children are young, the trends of the last three decades indicate that parents make time for children, even if they are spending more time at work. Gauthier et al. (2004) have analysed trends for persons living with at least one child under age five. The average time in child care is rising for both men and women. The average hours are higher for women than men, especially if 
Family Change and Implications for Family Solidarity and Social Cohesion

mothers are not employed. Although a higher proportion of women are employed, the average hours of child care for mothers of children under age five are rising for women as a whole.

Looking only at persons who worked at least three hours on the observation day and who were living with spouse and/or children, time-use surveys show an average decline in minutes spent with family, from 250 minutes in 1986 to 206 minutes in 2005 (Turcotte, 2007). The change over time was mostly associated with more time spent working and more time spent alone, including watching TV alone. Compared to the family structure involving a spouse but no children, there is more family time when there is at least one child aged $0-4$, or spouse and children aged 5-12. In lone parent families, children aged 5-12 do not increase family time, and there is significantly less family time in cases of lone parents with children aged 13-24. Non-standard work is also found to reduce family time, defined as time when parents and children are present together (Lapierre-Adamcyk et al., 2006; Rapoport and Le Bourdais, 2006). Shift work increases the time that fathers spend with children, but it has negative consequences on the overall family time (see also Presser, 2003).

\section{Family Change and Social Cohesion}

In his discussion of social capital, Coleman (1990) proposes that the family plays a crital role in the formation of the social capital enjoyed by its members. Lesthaeghe and Neels (2002) propose that the first demographic transition generated increased social cohesion through promoting a uniform family model based on prudent marriage and responsible parenthood. However, they see the second demographic transition as weakening the role of families in social cohesion, through secularization and the growing importance placed on individual autonomy. In particular, the family model based on intact marriages gave way to a diversity of family types corresponding to the interests in autonomy and post-material aspirations.

On the basis of the 2003 General Social Survey on Social Engagement, it is possible to identify three types of indicators of social capital, a measure of social cohesion, defined in terms informal networks, membership in organizations, and confidence in institutions. Table 5 shows the averages of measures of informal network by marital and parental status. Children do have an effect on both the size of networks and on the levels of trust and reciprocity with the influence varying by gender. Compared to those not living with children, the number of neighbours known is greater among men and women living with children. For women, those living with children have significantly greater number of relatives and friends. Levels of trust and reciprocity in family and neighbours of men 
Roderic Beaujot and Zenaida Ravanera

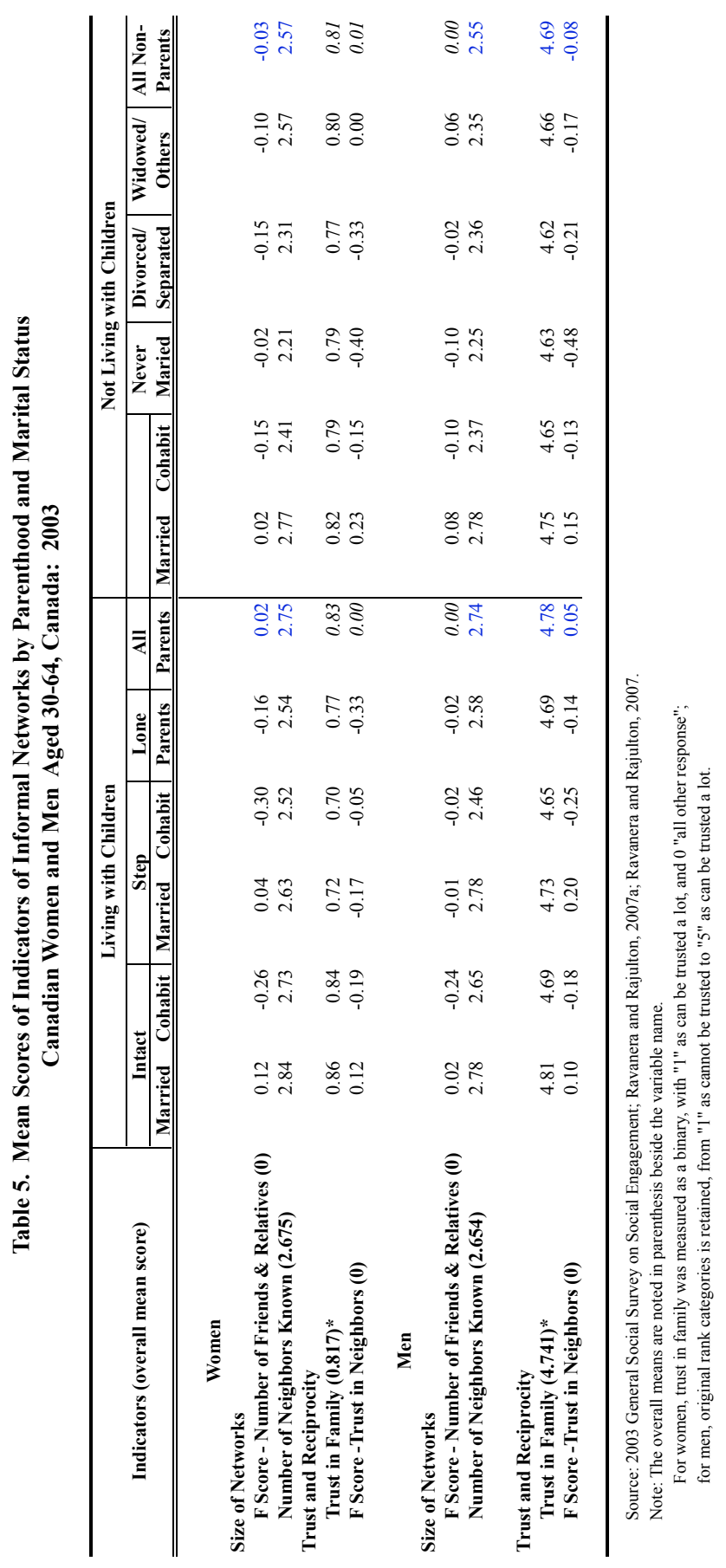


Family Change and Implications for Family Solidarity and Social Cohesion

living with children are also significantly higher compared to men not living with children.

Marital status makes a difference: married men and women whether living with children or not have greater number of friends and relatives, know many more neighbours, and have greater levels of trust in family and in neighbours than persons in other marital statuses.

In general, married men and women with children have also greater social capital measured in terms of organization membership, particularly in organizations that are related to families and neighbourhood, and have greater levels of confidence in government institutions (Ravanera and Rajulton, 2007a, 2007b.)

The network indicators have been further analysed with controls for economic (work status, education, income), and cultural factors (religiosity, region of residence), along with length of stay in the neighbourhood (Ravanera, 2006; Ravanera and Rajulton, 2007a, 2007b). These control factors may be operating as selectivity factors or as intervening variables between marital/parental status and social capital. Nonetheless, it can be concluded that marital and parental status do matter for both women and men, with more positive indicators of cohesion for parents and for married persons, along with more negative indicators for the lone parents, and for the never married and separated/divorced who are not living with children.

\section{Conclusion and Implications for Policies}

It is not easy to assess how family change has affected intra-family cohesion and social capital. Some changes have had positive effect such as families that are based on the desire of specific adults to be together, longer stay of children in parental home that allows greater parental investment, and greater tolerance for diversity of families. The majority of families have not experienced family dissolution through divorce or separation. Many children who have experienced the separation of their parents have had positive outcomes. And, family support system continues to operate within and across households.

This discussion has highlighted a number of the negative impacts of family changes. The shift in the foundation of families - from organic to mechanical solidarity - has weakened family relationships, with adverse effects particularly for children. Divorce and cohabitation have contributed to rising numbers of lone parent families, many headed by women, with negative consequences in 
children's development outcomes. The disadvantage for children from nonintact family starts from early in life (for instance, in behaviour and school outcome) and extends to early adulthood (as in leaving the parental homes early and in entry into cohabitation). Adults are also disadvantaged by family instability with, for instance, lower levels of social capital among those whose family lives have been disrupted.

In spite of the negative consequences of family changes, however, it is clearly not possible, nor is it advisable, to go back to the 1950s model of families. From all indications, the changes in the families will most likely continue with increases in collaborative models of families, and the best that could be done would be for society, through the state, to mitigate some of the adverse effects. Family, along with state and market, are key institutions in the modern welfare state (Esping-Andersen, 2001). While family is often considered to be a "private sphere," there is no doubt but that family questions are embedded into society's economic and political systems (Ravanera and McQuillan, 2006).

Many significant social policies affecting families were developed in an era of two-parent one-earner families. The relatively rapid population growth and youthful age structure provided the confidence that social programs would be sustainable. As McQuillan (2006: 295) observes, "many of the social policies that were developed in modern welfare states in the postwar period implicitly assumed that stable, intact families with a regularly employed breadwinner would guarantee the basic security of the great majority of the population." That is, many of the social policies provided for cases where the breadwinner had died, was disabled or unemployed. These policies have not always adapted to the new set of risks associated with family change (Esping-Andersen, 2001).

The lower prevalence of premature deaths mean less variability associated with widowhood and orphanhood, and more overlap of generations. However, on other grounds there is more variability, with more families formed through common-law unions, lone parenthood, and blended families, and lower proportions that are two-parent families based on marriage. While variability can be interpreted as a greater acceptance of alternatives, it also comes with a cost. For example, in the highest quintile of family income 93.9 percent of children are living with parents who are married to each other, but this is only 44.1 percent in the lowest income quintile (Péron et al., 1999: 248).

Societies have found some solutions for orphanhood (adoption), even orphanhood from one parent (Canada Pension Plan and other life insurance provisions), and also for the disability of one parent as long as that disability occurred at work (worker's compensation, Canada Pension Plan). We have not found ways to handle the unwillingness or inability of parent(s) to parent. 
Family Change and Implications for Family Solidarity and Social Cohesion

Consequently, besides encouraging parents to parent (child support obligations, joint custody), there needs to be a basis for children receiving support from the society (advance maintenance payments, guaranteed annual income). While day care, schools, and media have assumed greater roles in socialization, families remain the basis for taking care of the whole person and the long-term interests of children.

A focal point for social cohesion is children that can be considered society's "common project", and society must thus confront the issue of low fertility. There are indications that the value of children to family and society continues to be recognized. In spite of significant changes regarding sexuality and childbearing, Szreter (1996) considers that much sexual behaviour remains interpretable in terms of the perpetuation of "durable dyadic relationships and the rearing of children as two central sources of adult identity." Children reduce the risk of being alone. Anthropologists have long recognized the kinship ties and other relationships that come with children. Children enhance social integration, not only in terms of family ties but also in providing contact with others in the neighbourhood, at school, and in the community. In "Why do Americans want children," Schoen and his co-authors (1997) observe that people are more likely to intend to have another child when they attach importance to the social relationships created by children. This "social capital effect" is found to be strong across parity, union status, gender and race, with emphasis on primary group ties, along with affection, stimulation and fun, as intrinsic values of children. Schoen et al. (1997: 350) conclude by observing "Childbearing is purposive behaviour that creates and reinforces the most important and most enduring social bonds. Children are not seen as consumer durables, they are seen as the threads from which the tapestry of life is woven".

As Ravanera and McQuillan (2006: 10) note, the family continues to play a critical task in building human and social capital for children, providing social and emotional support for its members, and effectively and efficiently supplying aid to members in need. All of society benefits when families work well. Thus, it is in the private and public interest to support families to achieve their goals in workplace and at home. 
Roderic Beaujot and Zenaida Ravanera

\section{References:}

Amato, Paul R. and Alan Booth. 1997. A Generation at Risk: Growing up in an Era of Family Upheaval. Cambridge, Mass.: Harvard University Press.

Ariès, Philippe. 1962. Centuries of Childhood. New York: Knopf.

Astone, N.M., C.A. Nathanson, R. Schoen, and Y. J. Kim. (1999). "Family Demography, Social Theory, and Investment in Social Capital," Population and Development Review 25(1): 1-31.

Beaujot, Roderic. 2000. Earning and Caring in Canadian Families. Peterborough: Broadview.

Beaujot, Roderic and Ali Muhammad. 2006. "Transformed Families and the Basis for Childbearing.” In K. McQuillan and Z. R. Ravanera (eds) Canada's Changing Families: Implications for Individuals and Society. Toronto: University of Toronto Press. Pp. 15-48.

Beaujot, Roderic and Don Kerr. 2004. Population Change in Canada. Toronto: Oxford University Press.

Beaujot, Roderic and Don Kerr. 2007. "Emerging youth transition patterns in Canada: Opportunities and risks". Manuscript prepared for Policy Research Initiative.

Bernard, P. (1999). "Social Cohesion: A Critique." CPRN Discussion Paper No. F-09.

Bourdieu, P. (1985). The Forms of Capital. In J.G. Richardson (ed) Handbook of Theory and Research for Sociology of Education. New York: Greenwood. Pp. 241-58.

Burgess, E.W., H. Locke, and M. Thomas. 1963. The Family: From Institution to Companionship. New York: American.

Coleman, J.S. (1990). Foundations of Social Theory. Cambridge, MA: Belknap Press of Harvard University Press.

Coltrane, Scott. 1995. "The future of fatherhood.” In W. Marsiglio, Editor, Fatherhood. Thousand Oaks, Cal.: Sage.. Pp 255-274. 
Family Change and Implications for Family Solidarity and Social Cohesion

Côté, James E. and Anton L. Allahar. 1994. Generation on Hold: Coming of Age in the Late Twentieth Century. Toronto: Stoddart.

Cunningham, Frank.2000. A philosophical intervention. Paper presented at Social Cohesion Workshop, Toronto, 27-28 October 2000.

Dumas, Jean and Alain Bélanger. 1997. Report on the Demographic Situation in Canada 1996. Ottawa: Statistics Canada, cat. no. 91-209.

Dumas, Jean and Yves Péron. 1992. Marriage and Conjugal Life in Canada. Statistics Canada, cat. no. 91-534.

Durkheim, Emile. 1960 [1893]. The Division of Labour in Society. Glencoe, Ill.: The Free Press.

Drolet, Marie, 2002. Wives, Mothers and Wages: Does Timing Matter? Statistics Canada Cat. No. 11F0019 No. 186.

Esping-Andersen, G. 2001. Social Foundations of Postindustrial Economics. Oxford: Oxford University Press.

Farber, Bernard. 1964. Family Organization and Interaction. San Francisco: Chandler.

Feng, Yan, Sangita Dubay and Bradley Brooks. 2007. "Persistence of low income among working-aged unattached individuals." Income Research Paper Series, Statistics Canada Cat No. 75F0002MIE2007005.

Furstenberg, Frank F. 2005. "Banking on Families: How Families Generate and Distribute Social Capital." Journal of Marriage and the Family 67 (November): 809-821.

Freidan, Betty. 1963. The Feminine Mystique. New York: Norton.

Gauthier, Anne, Timothy Smeeding and Frank Furstenberg, 2004. "Are parents investing less in children? Trends in selected countries." Population and Development Review 30(4): 647-71

Goldscheider, Frances and Calvin Goldscheider. 1999. The Changing Transition to Adulthood: Leaving and Returning Home. Thousand Oaks, CA: Sage Publications. 
Roderic Beaujot and Zenaida Ravanera

Goldscheider, Frances and Linda J. Waite. 1991. New Families, No Families? Berkeley: University of California Press.

Haddad, Tony. 1998. "Custody Arrangements and the Development of Emotional and Behavioural Problems by Children." Presentation, Investing in Children Conference, Ottawa, October 1998.

Hareven, Tamara K. 1977. "Family Time and Historical Time." Daedalus 106,2: 57-70.

Jenson, J. (1998). Mapping Social Cohesion: The State of Canadian Research. Ottawa: Canadian Policy Research Network: Study No. F-03. 48Pp.

Juby, Heather and Céline Le Bourdais. 2005. "Families in transformation." Paper presented at the Human Resources and Social Development Canada (HRSDC) Expert Roundtable on Challenges for Canadian Families. Ottawa, December 1-2, 2005.

Kerr, Don. 2006. "The Evolving Family Living Arrangements of Canada's Children: Consequences for Child Poverty and Child Outcomes.” In K. McQuillan and Z. R. Ravanera (eds) Canada's Changing Families: Implications for Individuals and Society. Toronto: University of Toronto Press. Pp. 135-159.

Kiernan, K. 2002. "Demography and Disadvantage: Chicken and Egg?" Hills, J., J. LeGrand and D. Piachaud (eds.) Understanding Social Exclusion. Oxford University Press.

Lapierre-Adamcyk, Evelyne, Nicole Marcil-Gratton, and Céline Le Bourdais. 2006. "A Balancing Act: Parents' Work Arrangements and Family Time.” In K. McQuillan and Z. R. Ravanera (eds) Canada's Changing Families: Implications for Individuals and Society. Toronto: University of Toronto Press. Pp. 49-75.

Le Bourdais, Céline. and Évelyne Lapierre-Adamcyk. 2004. "Changes in Conjugal Life in Canada - Is Cohabitation Progressively Replacing Marriage?" Journal of Marriage and Family 66: 929-942.

Le Bourdais, Céline, Ghyslaine Neill and Nicole Marcil-Gratton. 2000. "L'effet du type d'union sur la stabilité des familles dites 'intactes'".

Recherches Sociographiques 41(1): 53-74. 
Family Change and Implications for Family Solidarity and Social Cohesion

Lesthaegue, Ron. 1995. "The Second Demographic Transition in Western Countries: An Interpretation.” In K. Oppenheim Mason and A. Jensen, (eds.), Gender and Family Change in Industrialized Countries. Oxford: Clarendon Press. Pp. 17-62.

Lesthaeghe, Ron and K. Neels. 2002. "From the First to the Second Demographic Transition - An Interpretation of the Spatial Continuity of Demographic Innovation in France, Belgium and Switzerland. European Journal of Population 18: 225-260.

Lochhead, Clarence. 2000. "The Trend Toward Delayed First Childbirth: Health and Social Implications." ISUMA: Canadian Journal of Policy Research Autumn: 41-44.

Luo, Zhong-Cheng, Russell Wilkins and Michael Kramer. 2004. "Disparities in pregnancy outcomes according to marital and cohabitation status." Obstetrics and Gynecology 103(6): 1300-1307.

Marshall, Katherine. 2007. "The busy life of teens." Perspectives on Labour and Income 19(2): 5-15.

Mac Con, Karen. 2006. "The Impact of Family Context on Adolescent Emotional Health during the Transition to High School." In K. McQuillan and Z. R. Ravanera (eds) Canada's Changing Families: Implications for Individuals and Society. Toronto: University of Toronto Press. Pp. 160-178.

McLanahan, Sara. 2004. "Diverging Destinies: How Children Are Faring Under the Second Demographic Transition.” Demography 41: 607-627.

McQuillan, Kevin. 2006. "Conclusion: Family Change and the Challenge for Social Policy. In K. McQuillan and Z. R. Ravanera (eds) Canada's Changing Families: Implications for Individuals and Society. Toronto: University of Toronto Press. Pp. 203-306.

Myles, John, Feng Hou, Garnett Picot, and Karen Myers. 2006. Why Did Employment and Earnings Rise Among Lone Mothers During the 1980s and 1990s. Analytical Studies Branch Research Paper Series. Statistics Canada Cat. \# 11F0019MIE No. 282.

Oppenheimer, Valerie. 1988. "A Theory of Marriage Timing: Assortative Mating under Varying Degrees of Uncertainty." American Journal of Sociology 94: 563-591. 
Roderic Beaujot and Zenaida Ravanera

Oppenheimer, Valerie K.1997. "Women's Employment and the Gain to Marriage: The Specialization and Trading Model." Annual Review of Sociology 23: 431-53.

Péron, Yves, Hélène Desrosiers, Heather Juby, Evelyne Lapierre-Adamcyk, Céline Le Bourdais, Nicole Marcil-Gratton, and Jael Mongeau. 1999. Canadian Families at the Approach of the Year 2000. Ottawa: Statistics Canada cat. no. 96-321 no.4.

Portes, A. 1998. "Social Capital: Its Origins and Applications in Modern Sociology." Annual Review of Sociology, 24:1-24.

Putnam, R.D. 1995. "Bowling Alone: America's Declining Social Capital." Journal of Democracy 6:65-78.

Putnam, R.D. 2000. Bowling Alone : The Collapse and Revival of American Community. New York : Simon \& Schuster.

Presser, Harriet. 2003. Working in a 24/7 Economy: Challenges for American Families. New York: Russell Sage.

Provencher, Claudine, Celine Le Bourdais, and Nicole Marcil-Gratton. 2006. Intergenerational Transfer: The Impact of Parental Separation on Young Adults' Conjugal Behaviour. In K. McQuillan and Z. R. Ravanera (eds) Canada's Changing Families: Implications for Individuals and Society. Toronto: University of Toronto Press. Pp. 179-209.

Rajulton, Fernando and Zenaida R. Ravanera. 2006. "Family Solidarity in Canada: An Exploration with the General Social Survey on Family and Community Support.” In K. McQuillan and Z. R. Ravanera (eds) Canada's Changing Families: Implications for Individuals and Society. Toronto: University of Toronto Press. Pp. 239-63.

Ranson, Gillian. 1998. "Education, Work and Family Decision Making: Finding the Right Time to Have a Baby." Canadian Review of Sociology and Anthropology 35: 517-33. 
Family Change and Implications for Family Solidarity and Social Cohesion

Rapaport, Benoit and Celine Le Bourdais. 2006. "Parental Time, Work Schedules, and Changing Gender Roles." In K. McQuillan and Z. R. Ravanera (eds) Canada's Changing Families: Implications for Individuals and Society. Toronto: University of Toronto Press. Pp. 76-104.

Ravanera, Z., F. Rajulton, and T.K. Burch. 2003. "Early life transitions of Canadian youth: Effects of family transformation and community characteristics," Canadian Studies in Population 30(2): 327-354.

Ravanera, Zenaida. 2007. Informal Networks Social Capital of Fathers: What Does the Social Engagement Survey Tell Us? Social Indicators Research 83(2):351-373.

Ravanera, Zenaida R. and Kevin McQuillan. 2006. "Introduction.” In K. McQuillan and Z. R. Ravanera (eds) Canada's Changing Families: Implications for Individuals and Society. Toronto: University of Toronto Press. Pp. 3-14.

Ravanera, Zenaida and Fernando Rajulton. 1996. "Stability and Crisis in the Family Life Course: Findings from the 1990 General Social Survey, Canada." Canadian Studies in Population 23,2: 165-84.

Ravanera, Zenaida R. and Fernando Rajulton. 2007a. "Membership in Organizations and Confidence in Institutions: Men's Social Capital and Its Differentials by Family Structures". Paper to be presented at the 2007 Annual Meeting of the Canadian Population Society. Saskatoon, May 31-June 2.

Ravanera, Zenaida R. and Fernando Rajulton. 2007b. "Social Capital of Women Measured: Differentials by Family Structures." Paper presented at the International Conference on Extended and Extending Families. Edinburgh, June 26-29, 2007.

Ravanera, Zenaida, Fernando Rajulton, and Thomas Burch.1998a. "Trends and Variations in the Early Life Courses of Canadian Men." University of Western Ontario, London, Ont.: Discussion Paper, no. 98-7.

Ravanera, Zenaida, Fernando Rajulton, and Thomas Burch. 1998b. "Early Life Transitions of Canadian Women: A Cohort Analysis of Timing, Sequences, and Variations." European Journal of Population 14: 179204. 
Roderic Beaujot and Zenaida Ravanera

Ravanera, Z.R. F. Rajulton, T.K. Burch and C. Le Bourdais. 2002. "The early life courses of Canadian men: Analysis of timing and sequences of events," Canadian Studies in Population 29: 293-312.

Rosell, S. A. et al. (1995). Changing Maps: Governing in a World of Rapid Change. Ottawa: Carleton University Press.

Roussel, Louis. 1979. "Générations nouvelles et mariage traditionnel." Population 34,1: 141-62.

Roussel, Louis. 1987. "Deux decennies de mutations demographiques (19651985) dans les pays industrializés." Population 42,3: 429-48.

Roussel, Louis. 1989. La famille incertaine. Paris: Editions Odile Jacob.

Scanzoni, Letha and John Scanzoni. 1976. Men Women and Change: A Sociology of Marriage and the Family. New York: McGraw-Hill.

Schoen, Robert, Young J. Kim, Constance A. Nathanson, Jason Fields, and Nan Marie Astone. 1997. "Why Do Americans Want Children?" Population and Development Review 23,2: 333-58.

Shorter, Edward. 1975. The Making of the Modern Family. New York: Basic Books.

Skolnick, Arlene. 1987. The Intimate Environment. Boston: Little, Brown.

Skolnick, Arlene. 1991. Embattled Paradise: The American Family in an Age of Uncertainty. New York: Basic.

Statistics Canada. 2002a. Profile of Canadian Families and Households: Diversification Continues. Statistics Canada Cat. No. 96F0030XIE2001003.

Statistics Canada. 2002b. Changing Conjugal Life in Canada. Statistics Canada Cat. No. 89-576-XIE.

Stone, Lawrence. 1977. The Family, Sex and Marriage in England 1500-1800. London: Weidenfeld and Nicolson.

Stone, W., M. Gray, and J. Hughes. 2003. "Social Capital at Work: An Australian Illustration.” Horizons 6(3) 55-60. 
Family Change and Implications for Family Solidarity and Social Cohesion

Szreter, Simon. 1996. "Falling Fertilities and Changing Sexualities in Europe since circa 1850." Canberra: Australia Natonal University Working Papers in Demography, no. 62.

Thadani, Veena. 1978. "The Logic of Sentiment: The Family and Social Change." Population and Development Review 4,3: 457-99.

Turcotte, Martin. 2007. "Time spent with family during a typical workday, 1986 to 2005." Canadian Social Trends 83: 2-11.

Veevers, Jean E. 1980. Childless by Choice. Toronto: Butterworths.

Waite, Linda J. 1995. “Does marriage matter?” Demography 32(4): 483-507.

Wu, Zheng. 1999. "Premarital Cohabitation and the Timing of First Marriage." Canadian Review of Sociology and Anthropology 36: 109-127.

Zhao, John, Fernando Rajulton and Zenaida Ravanera. 1995. "Leaving parental homes in Canada: Effects of family structure, gender, and culture." Canadian Journal of Sociology 20(1): 31-50. 